\title{
PEMBANDINGAN KINERJA TATA KELOLA BANK-BANK YANG BEROPERASI DI INDONESIA
}

\author{
Fongnawati Budhijono \\ Sekolah Tinggi Ilmu Ekonomi Wiyatamandala \\ fongnawati@wiyatamandala.ac.id
}

\begin{abstract}
Indonesian banking authorities consider corporate governance as one of the issues that can ensure the stability of the management of banks operating in Indonesia. Good corporate governance in banking is the governance of banks that apply the principles of transparency, accountability, responsibility, independence, and fairness. Good corporate governance in the banking sector is important because it can boost bank's and shareholder's profits in the long run. The focus of this study is to evaluate whether there are differences in the performance of bank governance in relation to the classification of BOOK (BUKU) established by the authorities. The study was conducted using secondary data obtained from Infobank Research Bureau (2017). In total there are 103 banks incorporated in various classifications of various BOOKS (BUKU) and also foreign banks. As the research variable is GCG Composite Value. This study is conducted by considering the bank grouping according to Bank Indonesia (BI) regulations on business activities of commercial banks (BUKU) and also banks belonging to the classification of foreign banks. The test were performed using ANOVA and multiple comparison with post hoc test. The result of the analysis stated that there is no difference of GCG composite value for banks belonging to different books (BUKU), including foreign banks.
\end{abstract}

Keyword: good governance, GCG, Banking Governance, BOOK classification, ANOVA.

\section{PENDAHULUAN}

Tata kelola perusahaan masih menjadi isu utama selama periode krisis pascakeuangan di pasar berkembang Asia, sepertihalnya Indonesia, Thailand, Filipina dan Malaysia. Secara khusus, lembaga keuangan telah menerapkan reformasi tata kelola perusahaan untuk meningkatkan perlindungan pemegang saham dan kepentingan pemangku kepentingan. Konsekuensi muncul karena memungkinkan pemantauan yang lebih besar terutama oleh pemegang saham. Tata kelola perusahaan yang baik di bidang perbankan adalah tata kelola bank yang menerapkan prinsip transparansi, akuntabilitas, tanggung jawab, independensi, dan kewajaran. Tata kelola perusahaan yang baik di bidang perbankan dipandang penting karena dapat meningkatkan keuntungan bank dan pemegang saham dalam jangka panjang. Otoritas perbankan Indonesia mendorong bank-bank yang beroperasi di Indonesia 
untuk memiliki peringkat tata kelola perusahaan yang baik. Bank yang beroperasi di Indonesia diwajibkan untuk melakukan penilaian terhadap bank secara individual dengan menggunakan pendekatan risiko (risk-based bank rating) dengan penilaian yang mencakup faktor profil risiko; Tata kelola perusahaan yang baik (GCG); Profitabilitas (pendapatan); dan modal (Surat Edaran BI, 2011). Orang-orang yang kurang menyadari pentingnya tata kelola perusahaan akan berpikir bahwa prosedur ketat bank dan kompensasi bunga yang rendah tidak menarik sehingga mereka lebih memilih untuk memilih bank dengan kenyamanan tinggi dan bank yang menawarkan imbalan bunga tinggi, terlepas dari kinerja bank dalam tata kelola perusahaan mereka. Fokus penelitian ini adalah untuk mengevaluasi apakah didapati perbedaan kinerja tata kelola bank sehubungan dengan klasifikasi BUKU yang ditetapkan oleh otoritas.

\section{TELAAH LITERATUR}

Sebagaimana dicatat oleh penelitian sebelumnya (Maria Praptiningsih,2009) tata kelola perusahaan tetap menjadi isu serius otoritas pengatur perbankan Indonesia. Otoritas perbankan Indonesia menganggap tata kelola perusahaan sebagai salah satu isu yang dapat menjamin stabilitas pengelolaan bankbank yang beroperasi di Indonesia (Peraturan Bank Indonesia, 2011). Tata kelola perusahaan yang baik di bidang perbankan adalah tata kelola bank yang menerapkan prinsip transparansi, akuntabilitas, tanggung jawab, independensi, dan kewajaran. Tata kelola perusahaan yang baik di bidang perbankan dipandang penting karena dapat meningkatkan keuntungan bank dan pemegang saham dalam jangka panjang. Otoritas perbankan Indonesia mendorong bank-bank yang beroperasi di Indonesia untuk memiliki peringkat tata kelola perusahaan yang baik. Bank yang beroperasi di Indonesia diwajibkan untuk melakukan penilaian terhadap bank secara individual dengan menggunakan pendekatan risiko (risk-based bank rating) dengan penilaian yang mencakup faktor profil risiko; Tata kelola perusahaan yang baik (GCG); Profitabilitas (pendapatan); dan modal (Surat Edaran BI, 2011).

Profil komposit Corporate Governance mencerminkan kemampuan bank dalam menerapkan prinsip-prinsip dasar GCG yang meliputi transparansi, akuntabilitas, tanggung jawab, independensi dan fairness. Penentuan profil komposit GCG Bank didasarkan pada analisis yang komprehensif dan terstruktur mengenai hasil implementasi prinsip tata kelola 
perusahaan dan juga informasi lainnya yang berkaitan dengan tata kelola bank. Ada lima peringkat komposit GCG yang mencerminkan sejauh mana bank dapat menerapkan prinsip-prinsip dasar tata kelola perusahaan. Peringkat satu adalah yang terbaik dan peringkat lima adalah yang terburuk. Atas dasar peringkat komposit GCG dan kinerja bank terkait GCG, Infobank Research Bureau (2017) menerbitkan nilai komposit GCG. Semakin tinggi nilai komposit GCG bank menunjukkan kinerja bank yang lebih baik dalam melakukan GCG.

Sejauh ini Otoritas perbankan Indonesia telah melakukan pengelompokan bank berdasarkan modal inti atau berdasarkan kegiatan usaha (bank umum kegiatan usaha atau BUKU) dan asset, mulai dari BUKU 4 hingga BUKU 1. Bank-bank yang tergolong dalam BUKU 4 bermodal inti Rp 30 trilyun ke atas, bank-bank yang tergolong dalam BUKU 3 bermodal inti Rp 5 trilyun sampai dengan dibawah $\mathrm{Rp}$ 30 trilyun, bank-bank yang tergolong dalam BUKU 2 bermodal inti Rp 1 trilyun sampai dengan dibawah Rp 5 trilyun dan bank-bank yang tergolong dalam BUKU 1 bermodal inti dibawah Rp 1 trilyun.

Kepentingan pihak perbankan dalam melakukan pengelolaan tata kelola bank dapat dikaitkan dengan keperluan pihak bank untuk menjawab regulasi yang ditetapkan otoritas maupun untuk meningkatkan kepercayaan masyarakat terhadap bank. Bank-bank yang tergolong pada klasfikasi BUKU yang makin tinggi semestinya melakukan tata kelola yang lebih baik mengingat tanggung jawab yang diembannya dalam pengelolaan dana juga makin tinggi. Bagaimanapun juga pengelolaan bank yang makin baik membutuhkan sumber daya yang makin besar pula. Di lain sisi kenyataan di lapangan menunjukkan bahwa pada umumnya nasabah bank belum menyadari pentingnya tata kelola perusahaan pada bank. Sejauh ini bahkan orang lebih menghargai tingkat suku bunga yang tinggi, kemudahan prosedur pemberian pinjaman sehingga pada akhirnya bankbank yang memiliki GCG-CG rendah memiliki NIM yang tinggi. Bank dengan GCG-CG yang tinggi biasanya akan lebih ketat dalam prosedur operasionalnya dan juga memberikan tingkat bunga yang lebih rendah. Orang-orang yang kurang menyadari pentingnya tata kelola perusahaan akan berpikir bahwa prosedur ketat bank dan kompensasi bunga yang rendah tidak menarik sehingga mereka lebih memilih untuk memilih bank dengan kenyamanan tinggi dan bank yang menawarkan imbalan bunga tinggi, terlepas dari kinerja bank dalam tata kelola perusahaan mereka. Fokus penelitian ini 
adalah untuk mengevaluasi apakah didapati perbedaan kinerja tata kelola bank sehubungan dengan klasifikasi BUKU yang ditetapkan oleh otoritas.

\section{METODOLOGI PENELITIAN}

Penelitian dilakukan dengan menggunakan data sekunder yang diperoleh dari Biro Penelitian Infobank (2017). Sebagai variabel penelitian adalah Nilai Komposit GCG (NKGCG). Studi ini dilakukan dengan mempertimbangkan pengelompokan bank sesuai peraturan Bank Indonesia (BI) pada kegiatan usaha bank umum (BUKU) dan juga bank-bank yang tergolong dalam klasifikasi bank asing.

Pengujian dilakukan dengan menggunakan ANOVA. Sebagai variabel independen adalah BUKU dan Kelompok Bank Asing. Pengujian dilakukan terhadap kinerja GCG yang dalam hal ini digunakan Nilai Komposit GCG (NKGCG) sebagai indicator kinerja GCG dari bank.

Dalam melakukan pengujian diberlakukan kode sebagai berikut:

- $\quad$ Bank-bank yang tergolong dalam BUKU 1 diberi kode 1

- $\quad$ Bank-bank yang tergolong dalam BUKU 2 diberi kode 2

- $\quad$ Bank-bank yang tergolong dalam BUKU 3 diberi kode 3
- Bank-bank yang tergolong dalam BUKU 4 diberi kode 4

- $\quad$ Bank-bank yang tergolong dalam Bank Asing diberi kode 5

Dalam penelitian ini ditetapkan hipotesis sebagai berikut:
$\mathrm{H}_{0}$ : Tidak didapati perbedaan nilai komposit GCG untuk bank-bank yang tergolong dalam buku yang berbeda maupun bank asing
$\mathrm{H}_{\mathrm{a}}$ : Paling sedikit didapati adanya perbedaan nilai komposit GCG untuk bank yang tergolong dalam suatu buku dengan buku yang lain maupun bank asing

\section{HASIL DAN PEMBAHASAN}

Secara keseluruhan terdapat 103 bank yang tergabung dalam berbagai klasifikasi berbagai BUKU dan klasifikasi bank asing. Dari 103 bank yang ditelaah, didapati 24 bank yang tergolong dalam klasifikasi BUKU 1, sebanyak 50 bank tergolong dalam klasifikasi BUKU 2, sebanyak 18 bank yang tergolong dalam klasifikasi BUKU 3, sebanyak 7 bank yang tergolong dalam klasifikasi BUKU 4, dan sebanyak 4 bank yang tergolong dalam klasifikasi bank Asing. Deskripsi dari 103 bank dalam berbagai klasifikasi ditunjukkan pada Tabel 1. 
Tabel 1. Hasil Statistik Deskriptif

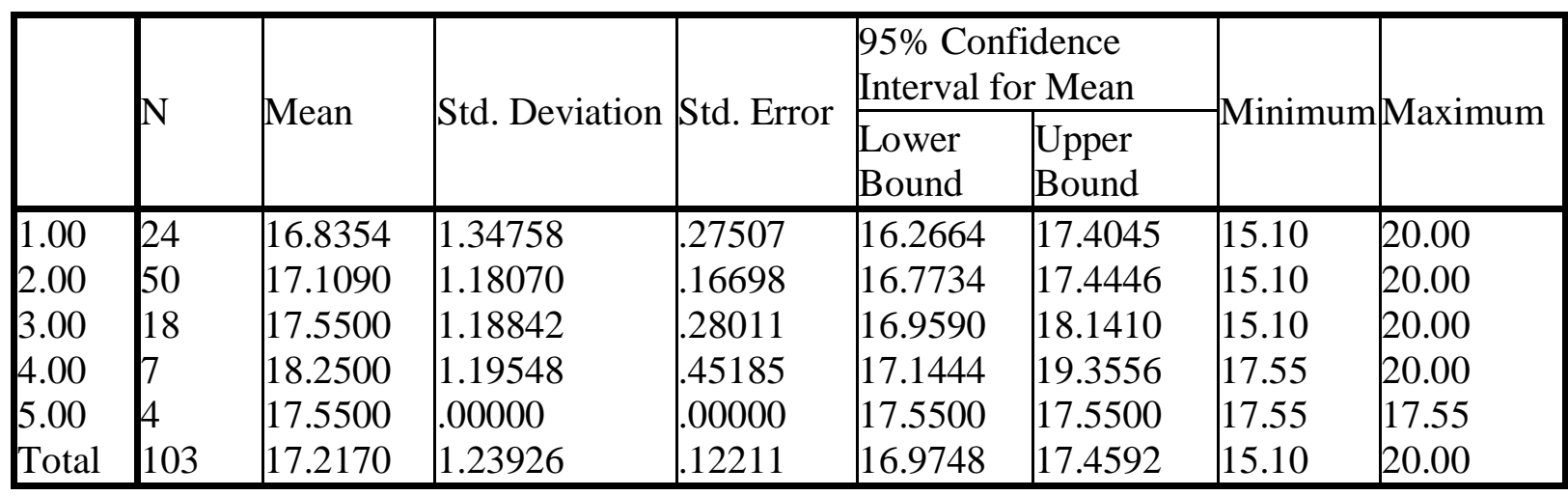

Dari tabel 1 diketahui bahwa nilai rata-rata tertinggi untuk Nilai Komposit GCG didapat pada bank-bank yang tergolong dalam klasifikasi BUKU 4 (dengan nilai mean sebesar 18.250) . Nilai rata-rata terendah untuk Nilai Komposit GCG didapat pada bank-bank yang tergolong dalam klasifikasi BUKU 1 (dengan nilai mean sebesar 16.8354). Hasil yang diperoleh dari statistika deskriptif ini sejalan dengan ekspektasi bahwa dengan semakin tinggi besarnya dana inti yang dikelola bank semestinyalah makin tinggi kinerja tata kelola banknya yang dalam hal ini direpresentasikan oleh Nilai Komposit GCG. Hasil analisis deskriptif juga menyatakan bahwa kinerja tata kelola bank dari bank-bank asing tidak lebih baik dari bank-bank non bank asing. Hal ini ditunjukkan oleh Nilai Komposit GCG bank asing dengan mean 17.550 yang sama nilainya dengan capaian dari bankbank yang tergolong dalam BUKU 3 . Namun demikian secara nominal terlihat bahwa kinerja Nilai Komposit GCG bankbank asing masih lebih baik dibandingkan kinerja Nilai Komposit GCG bank-bank yang tergolong dalam BUKU 1 dan BUKU 2, disamping juga bank-bank asing menunjukkan konsistensi yang sangat tinggi dalam hal kinerja Nilai Komposit GCG mereka (dengan standard deviation sama dengan 0.000). 
Tabel 2. Hasil ANOVA

\begin{tabular}{|l|l|l|l|l|l|}
\hline & $\begin{array}{l}\text { Sum of } \\
\text { Squares }\end{array}$ & df & Mean Square & F & Sig. \\
\hline Between Groups & 13.987 & 4 & 3.497 & 2.402 & .055 \\
Within Groups & 142.661 & 98 & 1.456 & & \\
Total & 156.648 & 102 & & & \\
\hline
\end{tabular}

Hasil dari ANOVA yang tertera pada Tabel 2 menunjukkan signifikansi sebesar 0.055 ( > 0.05) dengan demikian tidak cukup bukti untuk menolak Hipotesis nol. Hasil pengujian atas dasar data yang terkumpul menyatakan tidak didapati perbedaan nilai komposit GCG untuk bank-bank yang tergolong dalam buku yang berbeda dan juga bank asing. Hasil dari ANOVA menyatakan bahwa ekspektasi dengan semakin tinggi besarnya dana inti yang dikelola bank semestinyalah makin tinggi kinerja tata kelola banknya yang dalam hal ini direpresentasikan oleh Nilai Komposit GCG tidak tercapai. Namun demikian perolehan ini justru menunjukkan kemampuan otoritas perbankan Indonesia dalam mengelola kinerja GCG bank-bank yang beroperasi di Indonesia. Tidak peduli berapa besarnya dana inti bank-bank yang beroperasi di Indonesia, kinerja nilai komposit GCG mereka dapat dikelola tidak berbeda signifikan satu sama lain.
Pengujian lebih lanjut menggunakan multiple comparison dengan uji Tukey HSD pada post hoc test sebagaimana tampak pada Tabel 3 mengkonfirmasi temuan ANOVA. Hasil pengujian dengan Tukey HSD menunjukkan tidak didapati perbedaan nilai komposit GCG untuk bank-bank yang tergolong dalam buku yang berbeda dan juga bank asing. Meskipun hasil yang diperoleh menunjukkan tidak didapati perbedaan nilai komposit GCG untuk bank-bank yang tergolong dalam buku yang berbeda dan bank asing, pengujian terhadap bank-bank yang tergolong dalam buku 1 dan buku 4 menunjukkan signifikansi sebesar 0.057 yang mendekati salah jenis 1 yang ditetapkan sebesar 0.05, dalam arti kinerja good corporate governance kedua kelompok buku bank tersebut terkait nilai komposit GCG nya hampir berbeda signifikan. 
Tabel 3. Hasil Multiple Comparison

\begin{tabular}{|c|c|c|c|c|c|c|c|}
\hline \multirow{2}{*}{ Tukev HSD } & (I) Buku & (J) Buku & Mean Difference (I-J) & Std. Error Sig. & \multicolumn{3}{|c|}{$\begin{array}{l}\text { 95\% Confidence Interval } \\
\text { Lower Bound Upper Bound }\end{array}$} \\
\hline & 1.00 & 2.00 & -.27358 & .29962 & .891 & -1.1063 & .5591 \\
\hline & & 3.00 & -.71458 & .37620 & .325 & -1.7601 & .3310 \\
\hline & & 4.00 & -1.41458 & .51828 & .057 & -2.8550 & .0258 \\
\hline & & 5.00 & -.71458 & .65160 & .808 & -2.5255 & 1.0964 \\
\hline & 2.00 & 1.00 & .27358 & .29962 & .891 & -.5591 & 1.1063 \\
\hline & & 3.00 & -.44100 & .33164 & .673 & -1.3627 & .4807 \\
\hline & & 4.00 & -1.14100 & .48690 & .140 & -2.4942 & .2122 \\
\hline & & 5.00 & -.44100 & 62693 & .955 & -2.1834 & 1.3014 \\
\hline & 3.00 & 1.00 & .71458 & .37620 & .325 & -.3310 & 1.7601 \\
\hline & & 2.00 & .44100 & .33164 & .673 & -.4807 & 1.3627 \\
\hline & & 4.00 & -.70000 & .53743 & .690 & -2.1936 & .7936 \\
\hline & & 5.00 & .00000 & 66694 & 1.000 & -1.8536 & 1.8536 \\
\hline & 4.00 & 1.00 & 1.41458 & .51828 & .057 & -.0258 & 2.8550 \\
\hline & & 2.00 & 1.14100 & .48690 & .140 & -.2122 & 2.4942 \\
\hline & & 3.00 & .70000 & .53743 & .690 & -.7936 & 2.1936 \\
\hline & & 5.00 & .70000 & .75623 & .886 & -1.4017 & 2.8017 \\
\hline & 5.00 & 1.00 & .71458 & .65160 & .808 & -1.0964 & 2.5255 \\
\hline & & 2.00 & .44100 & 62693 & .955 & -1.3014 & 2.1834 \\
\hline & & 3.00 & .00000 & 66694 & 1.000 & -1.8536 & 1.8536 \\
\hline & & 4.00 & -.70000 & .75623 & .886 & -2.8017 & 1.4017 \\
\hline \multirow[t]{20}{*}{ LSD } & 1.00 & 2.00 & -.27358 & .29962 & .363 & -.8682 & .3210 \\
\hline & & 3.00 & -.71458 & .37620 & .060 & -1.4611 & .0320 \\
\hline & & 4.00 & $-1.41458^{*}$ & .51828 & .008 & -2.4431 & -.3861 \\
\hline & & 5.00 & -.71458 & .65160 & .275 & -2.0077 & .5785 \\
\hline & 2.00 & 1.00 & .27358 & .29962 & .363 & -.3210 & .8682 \\
\hline & & 3.00 & -.44100 & .33164 & .187 & -1.0991 & .2171 \\
\hline & & 4.00 & $-1.14100^{*}$ & .48690 & .021 & -2.1072 & -.1748 \\
\hline & & 5.00 & -.44100 & .62693 & .483 & -1.6851 & .8031 \\
\hline & 3.00 & 1.00 & .71458 & .37620 & .060 & -.0320 & 1.4611 \\
\hline & & 2.00 & .44100 & .33164 & .187 & -.2171 & 1.0991 \\
\hline & & 4.00 & -.70000 & .53743 & .196 & -1.7665 & .3665 \\
\hline & & 5.00 & .00000 & 66694 & 1.000 & -1.3235 & 1.3235 \\
\hline & 4.00 & 1.00 & $1.41458^{*}$ & .51828 & .008 & .3861 & 2.4431 \\
\hline & & 2.00 & $1.14100^{*}$ & .48690 & .021 & .1748 & 2.1072 \\
\hline & & 3.00 & .70000 & .53743 & .196 & -.3665 & 1.7665 \\
\hline & & 5.00 & .70000 & .75623 & .357 & -.8007 & 2.2007 \\
\hline & 5.00 & 1.00 & .71458 & .65160 & .275 & -.5785 & 2.0077 \\
\hline & & 2.00 & .44100 & .62693 & .483 & -.8031 & 1.6851 \\
\hline & & 3.00 & .00000 & .66694 & 1.000 & -1.3235 & 1.3235 \\
\hline & & 4.00 & -.70000 & .75623 & .357 & -2.2007 & .8007 \\
\hline
\end{tabular}

*. The mean difference is significant at the 0.05 level. 
Hasil analisis dengan LSD menunjukkan tampilan yang berbeda. Pengujian dengan LSD memberlakukan kriteria penolakan yang lebih longgar dibandingkan Uji Tukey. Kinerja nilai komposit GCG dari bank-bank yang tergolong dalam buku 1 dan buku 4 (dengan signifikansi $0.008<$ 0.05) menunjukkan perbedaan yang signifikan. Kinerja nilai komposit GCG dari bank-bank yang tergolong dalam buku 2 dan buku 4 juga menunjukkan perbedaan yang signifikan (dengan signifikansi 0.021 $<$ 0.05). Kinerja Nilai Komposit GCG bank-bank yang tergolong BUKU 4 signifikan lebih baik dibadingkan bankbank yang tergolong BUKU 1 maupun BUKU 2. Kinerja nilai komposit GCG dari bank-bank yang tergolong dalam buku 1 dan buku 3 (dengan signifikansi 0.06) nyaris menunjukkan perbedaan yang signifikan.

Meskipun hasil analisis yang didasarkan uji Tukey dan uji LSD menyatakan perolehan yang berbeda, dengan pertimbangan kinerja GCG sangatlah penting bagi bank untuk menjawab keperluan pihak bank untuk menjawab regulasi yang ditetapkan otoritas maupun untuk meningkatkan kepercayaan masyarakat terhadap bank dalam mengelola dana pihak ketiga, maka simpulan akan didasarkan atas hasil pengujian yang lebih ketat, yaitu menggunakan hasil uji Tukey. Dengan demikian meskipun hasil analisis deskriptif menunjukkan adanya beda nilai nominal sehubungan nilai rata-rata nilai komposit GCG berbagai bank dalam berbagai klasifikasi BUKU dan juga bankbank asing, perbedaan yang ditampilkan tersebut belumlah menyatakan beda yang signifikan.

\section{SIMPULAN}

1. Hasil analisis menyatakan tidak didapati perbedaan nilai komposit GCG untuk bank-bank yang tergolong dalam buku yang berbeda, termasuk di dalamnya bank-bank asing.

2. Ekspektasi dengan semakin tinggi besarnya dana inti yang dikelola bank semestinyalah makin tinggi kinerja tata kelola banknya yang dalam hal ini direpresentasikan oleh Nilai Komposit GCG tidak tercapai.

3. Perolehan analisis ini menunjukkan kemampuan otoritas perbankan Indonesia dalam mengelola kinerja GCG bank-bank yang beroperasi di Indonesia. Tidak peduli berapa besarnya dana inti bank-bank yang beroperasi di Indonesia, kinerja nilai komposit GCG mereka dapat dikelola oleh pihak otoritas perbankan Indonesia sehingga tidak berbeda signifikan satu sama lain. 


\section{DAFTAR PUSTAKA}

Akasha, Siddique, Adnan, Afzal Muhammad, Khan, Sajid Muhammad, Masood, Shoaib. 2014. Impact of Corporate Governance on Banks Performance. International Journal of Research in Social Sciences, 4, pp. 378- 391.

Bank Indonesia. 2011. Peraturan Bank Indonesia No.13/1/PBI/2011 tanggal 5 Januari 2011 perihal Penilaian Tingkat Kesehatan Bank Umum, pp. 4-10.

Bank Indonesia. 2011. Surat Edaran Bank Indonesia No.13/ 24 /DPNP/2011 tanggal 25 Oktober 2011 perihal Penilaian Tingkat Kesehatan Bank Umum, pp.1-28.

Infobank.2017. Rating 115 Bank di Indonesia, Infobank. XXXIX (466), pp. 20-29.

Karnoto Mohamad, Menilai Angka dan Kualitatif Bank, Infobank, no 437, vol XXXVII (411), 2015, pp. 26-31.

Nursiana, Adinoto. 2015. Pengaruh Internet Banking, Kualitas Layanan, Reputasi Produk, Lokasi Terhadap Loyalitas Nasabah Dengan Intermediasi Kepuasan Nasabah. Jurnal Keuangan dan Perbankan,19(3),pp.450-462.

Praptiningsih, Maria. 2009. Corporate Governance and Performance of Banking Firms: Evidence from Indonesia, Thailand, Philippines, and Malaysia. Jurnal Manajemen dan Kewirausahaan Faculty of Economics, Department of Management - Petra Christian University.
Sugiarto, Performance Evaluation of Indonesian Banks and Foreign Banks Operating in Indonesia Related to Classification of Capital. Advances in Economics. 2016. Proceeding Business and Management Research, Volume 15, $1^{\text {st }}$ Global Conference on Business, Management and Entrepreneurship (GCBME-16). Atlantis Press, 1. pp. 104-108.

Sugiarto \& Nursiana Adinoto. 2016. Determinants Identification of Public Banks Stock Prices in Indonesia Based On Fundamental Analysis. International Journal of Applied Business and Economic Research. 14(6),pp. 4705-4712. 